\title{
Cytokine Profile of a Holstein Calf with Bovine Leukocyte Adhesion Deficiency during the Acute-Phase Inflammatory Response
}

\author{
Hajime NAGAHATA $^{1)}$, Katsuro HAGIWARA ${ }^{2)}$, Masahiko KASAMATSU ${ }^{1)}$, Hidetoshi HIGUCHI ${ }^{1)}$ and \\ Takashi KUROSAWA ${ }^{3)}$ \\ ${ }^{1)}$ Departments of Animal Health, ${ }^{2)}$ Veterinary Microbiology and ${ }^{3)}$ Veterinary Internal Medicine, School of Veterinary Medicine, Rakuno \\ Gakuen University, 582 Bunkyodai-Midori, Ebetsu, Hokkaido 069-8501, Japan
}

(Received 10 May 2002/Accepted 8 August 2002)

ABSTRACT. Changes in interleukin (IL)-1 $\beta$, IL-6 and IL-8 in serum, and their mRNA expression on neutrophils from a 4.6-month old Holstein young calf with bovine leukocyte adhesion deficiency (BLAD) during the acute phase were evaluated. IL- $1 \beta$ concentrations in the serum of the calf with BLAD at age 143-162 days ranged from 8.7 to $16.6 \mathrm{ng} / \mathrm{ml}$, whereas the values were less than $2.7 \mathrm{ng} / \mathrm{ml} \mathrm{in}$ control calves. Serum IL-6 $(0.04 \mathrm{ng} / \mathrm{m} l)$ was only detected on the 1 st day when the animal was diagnosed with the BLAD. IL- $1 \beta$ and IL-8 mRNA expression on neutrophils from the affected calf appeared to be similar to those of controls. Serum cytokine levels and their mRNA expression on neutrophils from the calf with BLAD appeared to be little affected by the deficient expression of $\beta_{2}$-integrin on leukocytes, and are considered to be modulated by the inflammatory stimuli.

KEY WORDS: acute phase, CD18-deficiency, cytokine.

J. Vet. Med. Sci. 64(12): 1141-1143, 2002

Bovine leukocyte adhesion deficiency (BLAD) is a hereditary disorder characterized by defective expression of leukocyte adhesion glycoproteins LFA-1 (CD11a/CD18), Mac-1 (CD11b/CD18), and p150,95 (CD11c/CD18), each with a separate $\alpha$ chain and a common $\beta$ chain (CD18) $[11,14]$. The clinical features, the functional neutrophil abnormalities, pathologic findings and genetic analysis of BLAD-affected cattle have been fully elucidated; however, the cytokine profiles of BLAD-affected cattle during the early acute phase inflammatory response remain to be evaluated. An inflammatory response is initiated by the release of inflammatory mediators. Cytokines, including tumour necrosis factor (TNF)- $\alpha$, IL- $\beta$, IL- 6 and IL- 8 , are produced by human neutrophils and are likely to play an active role in the pathogenesis of neutrophilic diseases [3]. As for the inflammatory cytokines produced by neutrophils from domestic animals, Joubert et al. [10] reported that equine neutrophils produce mRNA for TNF- $\alpha$, IL- $\beta$, IL-6, IL-8 and macrophage inflammatory protein (MIP)-2, and expression of individual cytokine mRNA varies according to the state and duration of neutrophil activation. However, to our knowledge, only IL-1 mRNA expression by bovine neutrophils has been reported [1,2], and little is known about the cytokine profiles of bovine neutrophils under various diseased conditions. It is therefore of interest to clarify whether cytokine profiles of neutrophils from cattle with BLAD are modified with deficient expression of $\beta_{2}$-integrin (CD11a,b, and c/CD18) on leukocytes during the acute phase inflammatory response. This report describes the cytokine profile and selected immunological findings of a calf with BLAD in the acute phase of this disease.

A 4.6-month-old female Holstein-Friesian young calf showing weakness was reffered. Rectal temperature, heart and respiratory rates of the calf at admission were $40.2^{\circ} \mathrm{C}$,
92 beats/min and 40 times/min, respectively. The number of leukocytes ranged from 34 to $55.6 \times 10^{3} / \mu l$ and 80 to 90 $\%$ of them were segmented polymorphonuclear neutrophils. The affected calf was diagnosed as BLAD based on flow cytometric analysis of CD18 expression on isolated neutrophils [14]. Five-age matched healthy calves were used as controls.

Blood $(10 \mathrm{~m} l)$ was collected from the jugular vein into a heparinized tube $(20 \mathrm{IU} / \mathrm{m} l)$ and a tube without anticoagulant. Concentrations for Haptoglobulin (HP) and $\alpha-1$ acid glycoprotein ( $\alpha-1$ AG) in serum were measured by using a single radial diffusion kit (Saikin Kagaku Inc., Sendai). Serum $\gamma$-globulin was quantified by cellulose acetate electrophoresis, and the levels of serum immunoglobulin $(\mathrm{Ig}) \mathrm{G}$, IgM and IgA were measured using a commercially available assay kit (Saikin Kagaku Inc., Sendai). Isolation of neutrophils and mononuclear cells from peripheral blood was performed according to a method described previously [14]. Blastogenic response of lymphocytes to concanavalin A (con A) and phytohemagglutinin-P (PHA) was evaluated according to the procedure as described [13]. Cell-mediated cytotoxicity, natural killer (NK) activity and antibody dependent cell cytotoxicity (ADCC) of neutrophils were performed as described previously [15].

The concentrations of IL- $1 \beta$, IL- 6 and tissue necrosis factor (TNF)- $\alpha$ in the sera from the BLAD-calf were determined by a sandwich enzyme-linked immunoassay using IL- $1 \beta$, IL-6 and TNF- $\alpha$ specific antibodies, as described [8, 9]. The detection of cytokine mRNA (IL- $1 \beta$, IL- 6 and IL8 ) in neutrophils was performed as described $[8,16]$. The values were analyzed statistically by the Student's $t$-test.

Mean ( \pm SD) serum $\alpha-1$ AG concentrations in the calf during the period for 5 days after admission and 5 normal calves were $1358( \pm 67, \mathrm{n}=4)$ and $430( \pm 53) \mu \mathrm{g} / \mathrm{ml}$, and a 


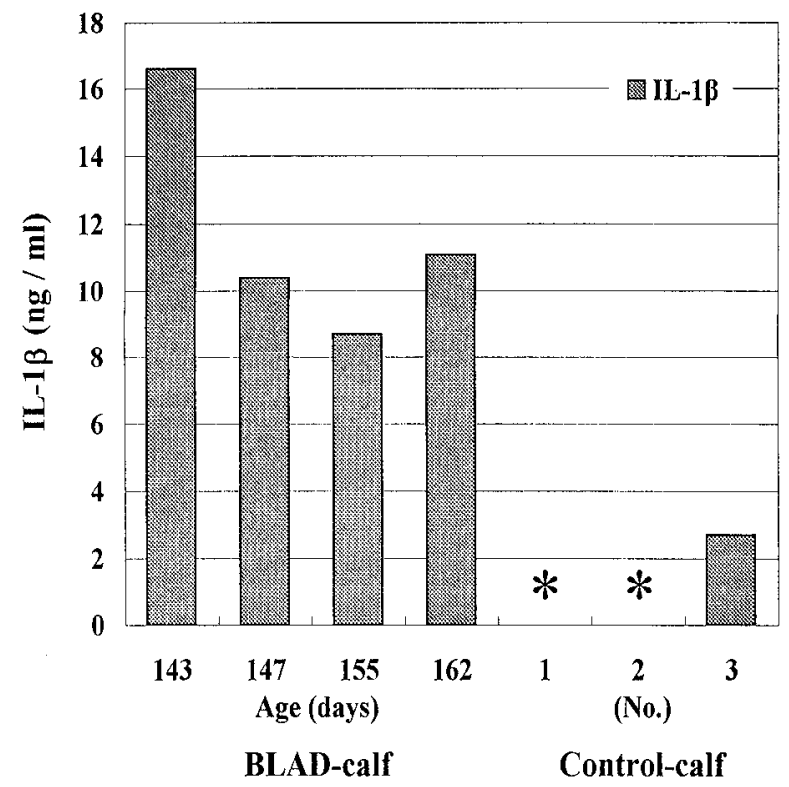

Fig. 1. Interleukin (IL)-1 $\beta$ levels in serum from the calf with bovine leukocyte adhesion deficiency (BLAD) and 3 normal calves.

3.2-fold higher value was found in the calf with BLAD. The concentrations of HP in serum from the affected calf and 5 normal calves were $2025( \pm 647, \mathrm{n}=4)$ and less than $20 \mu \mathrm{g} /$ $\mathrm{ml}$, respectively, and a marked elevation of HP in serum was observed in the calf with BLAD. Changes in these proteins, known as acute-phase reactants, indicated that the calf suf- fered from inflammatory stimuli [6].

Mean values (OD) of mitogen-induced blastogenic responses of lymphocytes from the affected calf and 3 control calves were 0.24 and 0.35 with con $\mathrm{A}$ and 0.19 and 0.26 with PHA, respectively, and were significantly different $(\mathrm{P}<0.05)$. NK and ADCC activities of neutrophils from the affected calf were 35 to $38.6 \%$ of those of control calves.

IL- $1 \beta$ was detected at a concentration of $16.6 \mathrm{ng} / \mathrm{ml}$ in serum from the affected calf aged 143 days at admission. Thereafter, the value ranged from 8.7 to $11.1 \mathrm{ng} / \mathrm{ml}$, whereas it was less than $2.7 \mathrm{ng} / \mathrm{ml}$ in control calves (Fig. 1). Serum IL-6 $(0.04 \mathrm{ng} / \mathrm{ml})$ was only detected on the day of diagnosis of BLAD (age 143 days). Thereafter, IL-6 activity was not detected, as in control calves. No TNF- $\alpha$ activity was detected in either the affected calf or controls.

Expression of mRNA for IL- $1 \beta$, IL- 6 and IL- 8 on neutrophils from the calf with BLAD and 2 normal calves was compared (Fig. 2). IL- $1 \beta$ and IL- 8 mRNA expression on neutrophils from the calf appeared to be similar to those of controls. IL-6 mRNA expression on neutrophils from the affected calf was faintly observed as compared with normal controls which expressed it clearly. IL-8 mRNA expression on mononuclear cells from the affected calf appeared to be low, compared to neutrophils from both the affected calf and controls.

The lymphocyte blastogenic response and cytotoxicity mediated by neutrophils in the calf with BLAD appeared to be low compared to those of control calves. Moreover, ADCC activity of neutrophils from the affected calf was low and different from a 4.8-year-old heifer with BLAD that showed enhanced immunoglobulin Fc receptor-mediated
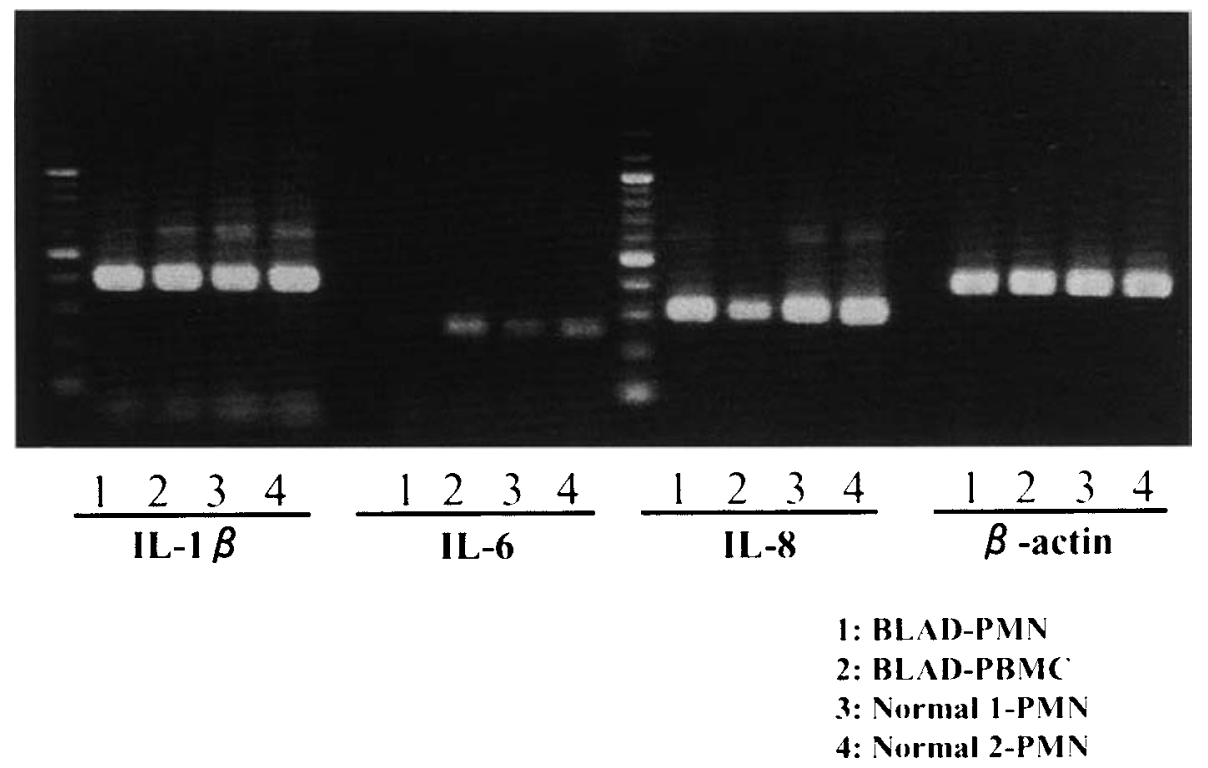

Fig. 2. Expression of mRNA for IL-1 $\beta$, IL-6 and IL-8 on neutrophils from the calf with bovine leukocyte adhesion deficiency (BLAD) and normal controls. Lanes 1: Neutrophils from the calf with BLAD. 2: Mononuclear cells from the calf with BLAD. 3: Neutrophils from normal calf No.1. 4: Neutrophils from normal calf No.2. $\beta$ - actin: internal standard. 
functions [15]. The discrepancy in leukocyte responses between the affected calf and heifer appeared to be due to the stage of inflammatory progress and duration.

The cytokines comprise a group of low molecular weight proteins that play a central role as mediators in the regulation of inflammation [18]. It is well documented that IL- $1 \beta$, IL- 6 and TNF- $\alpha$ are potent proinflammatory cytokines and are involved in the acute-phases of inflammation $[4,5,18]$. IL- $1 \beta$ contributes to the defense response against pathogens by generating fever, activating lymphocytes, and promoting the infiltration of leukocytes into the sites of infection [5]. However, little is known about the relationship between serum cytokine concentrations and their mRNA expression on neutrophils from cattle in the acute-phase response. In the present study, serum levels of IL- $1 \beta$ were found to be higher in the affected calf than in controls, indicating that it enhanced the production of acute-phase reactants, as indicated previously [7]. No TNF activity was detected in the affected calf, suggesting that the early phase of acute inflammation was transient, because this cytokine could be found in initial phase of acute inflammation as reported previously in experimental dogs with acute inflammation, i.e, within $24 \mathrm{hr}$ after challenge with stimulants [19]. IL-6 is a major inducer of acute-phase proteins in calves [17]. Interestingly, only IL- 6 was detected in the serum from the calf with BLAD, suggesting that IL- 6 may be associated with induction of acute-phase proteins. Serum IL-6 and TNF activities precede serum concentrations of CRP and $\alpha-1$ AG in dogs with experimentally induced acute-phase responses [19]. It has been reported that serum concentrations of bovine HP and fibrinogen increase in a manner similar to those in cattle with acute-phase reaction by continuous administration of recombinant human IL-6 [17].

It is clear that cytokines are the primary inducers of acute -phase protein gene expression and initiate different patterns of acute-phase proteins [18]. The intensity of mRNA for IL$1 \beta$ and IL- 8 on neutrophils from the affected calf was similar to those found in control neutrophils from 2 normal calves; however, mRNA for IL-6 on neutrophils was relatively low in the affected calf. A discrepancy between the serum IL-6 level and its mRNA expression was observed. This finding indicated that the serum IL- 6 detected in the affected calf was produced by a variety of cells, including $\mathrm{T}$ lymphocytes, monocytes and fibroblasts [11]. Cytokine levels in serum and their mRNA expression on neutrophils from the calf with BLAD during the acute-phase period were modulated and appeared to be clearly different from those found in a 4.8-year-old heifer with BLAD, which had a chronic course of recurrent infections that showed more highly increased cytokine levels and mRNA for IL- $\beta$, TNF- $\alpha$, IL-6 and IL- 8 on neutrophils [16].

In conclusion, selected cytokine profiles found in the calf with BLAD reflected the changes in the acute-phase response during the early period of inflammation. Serum cytokine levels and their mRNA expression on neutrophils from the calf appeared to be little affected by the deficient expression of $\beta_{2}$-integrin on leukocytes, and were likely modulated by the inflammatory stimuli.

ACKNOWLEDGEMENTS. This study was supported in part by a Grant-in-Aid for Scientific Research Fund (No.11460146) from the Japan Society for the Promotion of Science and by Frontier Research Grant from the Ministry of Education, Science and Culture, Japan. The authors would like to thank Mr. M. K. Barrymore for his critical reading of the manuscript.

\section{REFERENCES}

1. Beckman, M. J., Sotos, J., Leite, F., Schuler, L. A. and Czuprynski, C. J. 2000. Vet. Immunol. Immunopathol. 77: 221232.

2. Canning, P. C. and Neill, J. D. 1989. J. Leukoc. Biol. 45: 2128.

3. Cassatella, M. A. 1995. Immunol. Today 16: 21-26.

4. Dinarello, C. A. 1984. Surv. Immunol. Res. 3: 29-33.

5. Dinarello, C. A. 1996. Blood 87: 2095-2147.

6. Eckersall, P. D. and Conner. J. G. 1988. Vet. Res. Commun. 12: 169-178.

7. Godson, D. L., Baca-Estrada, M. E., Van Kessel, A.G., Hughes, H.P.A., Morsy, M.A., Van Donkersgoed, J.V., Harland, R.J., Shuster, D.E., Daley, M.J. and Babiuk, L.A. 1995. Can. J. Vet. Res. 59: 249-255.

8. Hagiwara, K., Kataoka, S., Yamanaka, H., Kirisawa, R. and Iwai, H. 2000. Vet. Immunol. Immunopathol. 76: 183-190.

9. Ito, M. and Kodama, M. 1996. Res. Vet. Sci. 60: 94-96.

10. Joubert, P., Silversides, D. W. and Lavoie, J.-P. 2001. Equine Vet. J. 33: 730-733.

11 Kehrli, M. E. Jr., Schmalstieg, F. C., Anderson, D. C., Van Der Maaten. M. J., Hughes, B. J., Ackermann, M. R., Wilhelmsen, C. L., Brown, G. B., Stevens, M. G. and Whetstone, C. A. 1990. Am. J. Vet. Res. 51: 1826-1836.

12. Kishimoto, 1989. Blood 74: 1-76.

13. Mosmann, T. 1983. J. Immunol. Methods 65: 55-63.

14. Nagahata, H., Kehrli, M. E. Jr., Murata, H., Okada, H., Noda, H. and Kociba, G. J.1994. Am. J. Vet. Res. 55: 40-48.

15. Nagahata, H., Higuchi, H. and Kasamatsu, M. 2000. Comp. Haematol. Int. 10: 102-104.

16. Nagahata, H., Hagiwara, K., Higuchi, H. and Kirisawa, R. 2002. J. Vet. Med. Sci. 64: 683-687.

17. Nakajima,Y., Momotani, E., Murakami, T., Ishikawa,Y., Morimatsu, M., Saito, M., Suzuki, H. and Yasukawa, K. 1993. Vet. Immunol. Immunopathol. 35: 385-391.

18. Van Miert, A.S.J.P.A.M. 2002. Vet. Res. Commun. 26: 111126.

19. Yamashita, K., Fujinaga, T., Miyamoto, T., Hagio, M., Izumisawa, Y. and Kotani, T. 1994. J. Vet. Med. Sci. 56: 487492. 